\title{
Management of Canalicular Trauma
}

\author{
J. P. ADENIS
}

Limoges, France

One of the most frequently encountered canalicular problems is canalicular injury. In the past repair was performed with canalicular intubation using various techniques. Presently many surgeons directly suture the lacerated ends of the canaliculus with canalicular intubation. In $1981 \mathrm{I}^{\text {described }}{ }^{1}$ the repair of lacerated canaliculi with direct canalicular sutures without intubation.

The purpose of this study is:

(1) To review the different techniques used in the past while pointing out some of their disadvantages.

(2) To report briefly our technique and our personal experience in 145 cases.

(3) To suggest the best approach for the repair of canalicular lacerations stressing the benefits of using a surgical microscope for the canalicular sutures.

\section{I-Different Techniques}

These different techniques can be classified into two groups:

1 Direct catheterisation.

2 Retrograde catheterisation.

(1) Direct catheterisation has been used by:

(a) Viers ${ }^{2}$ and Pico $^{3}$ with a canalicular rod with a silk suture swaged onto one end to bridge the two ends of the canaliculus. Sutures were then placed through the orbicularis, skin and conjunctiva. Such an end to end anastomosis in itself is not sufficient to ensure a permanently patent excretory lacrimal system when the rod is removed.

(b) Johnson ${ }^{4}$ substituted a canaliculus wire in place of the rod used by Viers to reapproximate the torn canaliculus. This permanent strong but lengthy intubation can damage the punctum creating too large an orifice. (c) Quickert and Dryden ${ }^{5}$ use a silastic tube carefully swaged onto the tapered end of special wires for a length of about $1 \mathrm{~cm}$. The wire is introduced into the lacrimal apparatus from the punctum crossing the laceration and then follows the normal contour of the nasalacrimal duct into the nose where it is retrieved. The most difficult part of the technique is to retrieve the malleable probe from the nose.

(d) The Garavis ${ }^{6}$ modification consists of the use of a silicone rubber tube swaged onto a malleable stainless steel lacrimal probe. The end of the silicone tube has a thin flat silastic plate to stop it from slipping into the canalicular system.

(e) Crawford ${ }^{7}$ uses a hook to retrieve the malleable probe from the nose. The probe must be specially designed to enter into the hook.

In 1982 we described a modification of the Crawford probe using a more malleable probe specially designed to connect the probe to the silastic tube. ${ }^{8}$

This probe was easier to retrieve from the nose.

(2) Retrograde intubation:

(a) Worst ${ }^{9}$ described the 'pig tail' probe allowing retrograde intubation. In his first design the pig tail ended in a small hook used to pull a large silk suture and then the silastic tube.

(b) Various modifications by Beyer, ${ }^{10}$ Busse, ${ }^{11}$ Hanselmayer $^{12}$ and Saunders ${ }^{13}$ were then described in which the pig tail probe ended with a small hole helpful in retrieving the silastic tube.

(c) Murube Del Castillo ${ }^{14}$ described a more physiological way of performing the intubation using a ring. Different techniques 
can be used to perform an annular intubation: Before introducing the tube a fine silk or prolene thread is inserted into the lumen. At the end of the operation the silicone tube is carefully cut a few millimeters from the puncta and the prolene thread is tightened. This is the best method. Otherwise a thick prolene thread can serve as a splint, the silicone ends being sutured together over it with a $9 / 0$ nylon.

Microsurgical sutures on the canaliculus:

To our knowledge Billson ${ }^{16}$ and Hanselmayer ${ }^{17}$ were the first to report results of direct suturing of the canaliculus with intubation. They used an annular silastic intubation to complete the repair. But the microsurgical technique was only briefly described.

\section{II-Personal Technique}

\section{(1) Direct sutures without intubation:}

In $1981^{1}$ and $1982^{18}$ we described a technique of direct suture with 10/0 nylon without any intubation. To our knowledge we were the first to describe this technique and report the result.

In order to approximate the two cut ends of the canaliculus we use a step by step technique.

(a) First we try to find the two rings of the cut ends of the canaliculus with the surgical microscope. The inner one is frequently retracted towards the sac due to contraction of the orbicularis muscle.

(b) Then a $4 / 0$ vicryl suture is placed under the cut ends in the outer part towards the tarsal plate, and in the inner part towards Horner's muscle. The suture is not tied at first.

(c) Afterwards the mucosa of the cut ends of the canaliculus is reapproximated with $8 / 0$ prolene sutures, which includes some of the surrounding connective tissue. Four or five sutures are placed and stuck in a special order on the surgical drape with 'steristrip'.

(d) The 4/0 vicryl suture is then tightened and finally the $8 / 0$ prolene sutures are tightened under microscopic control. Our first
25 cases were performed without any intubation.

(2) Furthermore in some difficult cases (lacerations near the sac, small loss of canalicular mucosa) we add a silastic intubation as described in the Murube technique.

\section{(3) Results}

(a) In 105 cases where we used various techniques without canalicular sutures (direct catheterisation, modified Quickert tubes, retrograde intubation) patent canaliculi were obtained in $50 \%$ of cases.

(b) In 40 cases where we used either canalicular sutures alone, or canalicular sutures with intubation we had only 4 cases of stenosis. Patent canaliculi were obtained in $90 \%$ of cases.

\section{III-Recommended Technique}

(1) A torn canaliculus is not an emergency. It should be sutured within 24 hours. Good results do not necessarily depend on the time interval between the injury and the repair, but mainly on whether a microsurgical repair is performed.

(2) A surgical microscope is necessary to repair injuries of the canaliculus. It helps to find the cut ends of the canaliculus, and enables proper placement of the stitches.

(3) In our hands, direct canalicular suturing increases the incidence of patent canaliculi postoperatively when compared to intubation without sutures.

(4) Is intubation always necessary?

(i) When the laceration is close to the lacrimal point we think canalicular sutures are all that are required to obtain a good result.

(ii) In difficult cases (canalicular mucosa loss, laceration near the sac), we suggest the combination of canalicular sutures and intubation with a silastic tube.

\section{References}

${ }^{1}$ Adenis JP: La réparation des plaies canaliculaires au monofilament: avec ou sans intubation. Premiers résultats. Bull Soc Opthalmol Fr 1981, 7: 180-1.

2 Veirs ER: Malleable rods for immediate repair of traumatically severed lacrimal canaliculus. Trans Am Acad Ophthalmol Otolaryngol 1962, 66: 263.

${ }^{3}$ Pico G: Repair of the freshly lacerated canaliculus. In the lacrimal system. E Veirs 1971, CV Mosby ed. pp 51-55. 
${ }^{4}$ Johnson CC: A canaliculus wire. Am J Ophthalmol 1974, 78: 854-???.

${ }^{5}$ Quickert MH and Dryden RM: Probes for intubation in lacrimal drainage. Trans Am Acad Ophthalmol Otolaryngol 1970, 74: 431.

${ }^{6}$ Gavaris PT: Current techniques in canalicular-lacrimal duct surgery. In: Bosniak S (ed): Advances in Ophthalmic Plastics and reconstructive surgery. Pergamon, (in press).

${ }^{7}$ Crawford JS: Intubation of obstructions in the lacrimal system. Canad J Ophthalmol 1977, 12: 28992.

${ }^{8}$ Adenis JP, Dufetelle JP, Robin A: Un nouveau systeme d'intubation lacrymale. J Fr Ophtalmol 1978, 1: 665-6.

${ }^{9}$ Worst JGE: Method for reconstructing torn lacrimal canaliculus. Am J Ophthalmol 1962, 53: 520-22.

${ }^{10}$ Beyer CK: A modified lacrimal probe. Arch Ophthalmol 1974, 92: 157-8.

${ }^{11}$ Busse H, Hollwich F, Junemann G: Plastische und rekonstruktive Chirurgie der Tränenwege. Ber Dtsch Ophthalmol Ges 1980, 77: 111.

${ }^{12}$ Hanselmayer $\mathrm{H}$ : Prognosis of injured canaliculi in relation to elapsed time until primary operation. Ophthalmologica 1973, 166: 175-9.
${ }^{13}$ Saunders DH, Shannon GM, Flanagan JC: The effectiveness of the pigtail probe method of repairing canalicular lacerations. Ophthalmic Surg 1978, 9: 33-40.

${ }^{14}$ Murube del Castillo J: L'intubation bicanaliculaire dans les sections des canalicules lacrimaux. Bull Mem Soc Fr Ophtalmol 1973, 86: 222-32.

${ }^{15}$ Hanselmayer H: Primäre rekonstruktion von Kanalikulus verletzungen. Klin Mon Augenheilk 1978, 173: 712-6.

${ }^{16}$ Billson FA, Taylor HR, Hoyt CS: Trauma to the lacrimal system in children. Am J Ophthalmol 1978, 96: 828-33.

${ }^{17}$ Hanselmayer $\mathrm{H}$ : Operations-Methoden und Spätergebnisse primär versorgter Kanalikulusverletzungen. In: Hanselmayer $\mathrm{H}$ : Neue Erkenntnisse über Erkrankungen der Tränenwege. Stuttgart 1981

${ }^{18}$ Adenis JP, Robin A: Une Nouvelle méthode de chirurgie canaliculaire: la suture au monofilament sans intubation. Etude de 23 cas. $J \mathrm{Fr}$ Ophtalmol 1982, 5: 515-8.

${ }^{19}$ Adenis JP, Robin A: Etude clinique et thérapeutique de 105 observations de traumatismes des canalicules lacrymaux. Bull Soc Oph Fr 1978, 11: 855-60. 